\title{
José Enrique Rodó, a “Geração Hispano-Americana de 98” e o projeto para uma identidade americana
}

\author{
Ricardo Amarante Turatti ${ }^{1}$
}

\section{Resumo:}

$\mathrm{O}$ artigo tem como objetivo analisar os projetos para a constituição de uma identidade americana. O estudo será desenvolvido tendo como foco a posição de intelectuais e literatos envolvidos na formação desses projetos, especificamente os que escreveram na virada do século XIX para o XX. Dentre esses autores, encontram-se os participantes do movimento literário conhecido como "Geração Hispano-Americana de 98", parte do modernismo hispano-americano. Para servir de exemplo para os modelos adotados para simbolizar a América, será realizado um estudo mais destacado das ideias de um dos autores da “Geração de 98”: o uruguaio José Enrique Rodó, autor do ensaio Ariel, publicado em 1900, e que pode ser considerado um manifesto desse movimento literário e político.

Palavras-chave: Identidade Americana; Modernismo Literário; José Enrique Rodó.

\begin{abstract}
:
The article intends to analyze the projects for the constitution of an American identity. The study focus the position of intellectuals and literati who have taken part in the formation of these projects, specifically those who wrote at the turn of the $\mathrm{XIX}^{\text {th }}$ to the $\mathrm{XX}^{\text {th }}$ century. Among these authors are the participants of the literary movement know as "SpanishAmerican Generation of 98", part of the Spanish-American Modernism. To provide an example for the models adopted to symbolize America, a detained study of the ideas of one of the authors from the "Generation of 98 " will be provided. This author is the Uruguayan José Enrique Rodó, author of the essay Ariel, published in 1900 and that can de considered a manifesto of this literary and political movement.
\end{abstract}

\footnotetext{
${ }^{1}$ Mestrando do Programa de Pós-Graduação em História Cultural da Universidade Estadual de Campinas (Unicamp). Título da pesquisa: Os espelhos da América: simbolização identitária, nos séculos XIX e XX, baseada em A tempestade, de William Shakespeare. E-mail: rramarante@uol.com.br.
}

Revista Eletrônica da ANPHLAC, n.13, p. 227-250, jul./dez. 2012. http://revista.anphlac.org.br/index.php/revista 
Keywords: American Identity; Literary Modernism; José Enrique Rodó.

A literatura produzida nos países hispano-americanos, durante o século XX, foi pródiga na produção e divulgação de reflexões e questionamentos sobre a identidade americana. Sob a forma de contos, ensaios e romances, diversos autores trouxeram sua visão sobre a cultura e o significado do "ser americano". Foi com a obra de Gabriel García Márquez $^{2}$, Jorge Luis Borges ${ }^{3}$ e Julio Cortázar ${ }^{4}$, entre outros, que a ficção produzida em países hispano-americanos atingiu seu ápice de popularidade - entre leitores e críticos - e de liberdade, nos comentários sobre a própria condição de americano. Um dos fatores que proporcionou essa liberdade foi o estilo presente em grande parte das obras desses autores, o chamado "realismo fantástico", que permite integrar acontecimentos insólitos e inusitados no fluxo da narrativa. É assim que, em Cem anos de solidão, de García Márquez, revoluções armadas e seus líderes são ao mesmo tempo satirizados e poetizados, enquanto a fictícia cidade de Macondo, amálgama de muitas regiões da chamada América Latina, é devorada por milhões de formigas (MÁRQUEZ, 2001, p. 381-3).

Além da liberdade estilística e poética, os textos literários e ensaísticos possuem também a capacidade de produzir questionamentos nas esferas filosófica e política, englobando diversas áreas e assuntos com uma facilidade maior do que a encontrada na escrita de trabalhos acadêmicos, por exemplo. Nas obras literárias e em alguns ensaios, não

\footnotetext{
${ }^{2}$ Gabriel José de la Concórdia García Márquez (1927- ): escritor e jornalista colombiano, autor de romances como Cem anos de solidão (1967), Crônica de uma morte anunciada (1981), O amor nos tempos do cólera (1985) e O general em seu labirinto (1989). Sua obra Cem anos de solidão foi um dos expoentes do movimento de popularização da literatura hispano-americana, conhecido como "o boom literário latinoamericano". Uma das marcas desse boom foi o realismo fantástico, e as obras literárias dos autores latinoamericanos atingiram diversos países, tendo sido consagradas por leitores e críticos de diversas línguas. García Márquez recebeu o Prêmio Nobel de Literatura em 1982.

${ }^{3}$ Jorge Francisco Isidoro Luís Borges (1899-1986): escritor argentino, um dos grandes nomes da literatura em língua espanhola do século XX, publicou diversos contos, poemas e ensaios. Utilizando uma profusão de simbolismos, que desembocam em uma profunda reflexão sobre o papel da literatura, da escrita e dos intelectuais, as obras de Borges representam um marco na moderna literatura, principalmente no que se refere a textos curtos. É autor de coletâneas de contos como Ficções (1944) e O Aleph (1949), além de volumes de poesia e ensaios sobre linguística e crítica literária.

${ }^{4}$ Julio Florencio Cortázar Descotte (1914-1984): contista, poeta e dramaturgo nascido na Bélgica, detentor das nacionalidades argentina e francesa. Filho de argentinos, desenvolveu uma técnica narrativa radical em seus textos, abrindo caminhos para o experimentalismo formal e linguístico na literatura em língua espanhola. É autor de obras como As armas Secretas (1959), Histórias de cronópios e de famas (1962) e O jogo da amarelinha (1963).
}

Revista Eletrônica da ANPHLAC, n.13, p. 227-250, jul./dez. 2012. http://revista.anphlac.org.br/index.php/revista 
existe uma exigência de especificidade científica, permitindo a seus autores transitarem por diversas áreas do conhecimento e até por diferentes formas de escrita. É nessa ampla construção de questionamentos que se encontra a emergência do intelectual, seja ele um literato, um ensaísta ou um crítico. A figura do intelectual, para a história das Américas nos séculos XIX e XX, é fundamental não apenas para nos permitir estudar fatos históricos, políticos e culturais, mas também para possibilitar a exploração de todo o campo de conhecimentos sendo divulgados e intercambiados. Por meio da leitura histórica e crítica de seus escritos e discursos, pode-se realizar um estudo sobre o surgimento de símbolos para a identidade americana, ou até mesmo realizar uma crítica do próprio termo "intelectual". Afinal, dizer intelectual é generalizar e rotular. Para se discutir a influência e o efeito do trabalho do intelectual, bem como as análises realizadas sobre esse trabalho, é útil recorrer à afirmação de Edward Said, que representa o intelectual como elemento ativo e transformador:

(...) Basta pôr as palavras "e" e "de" ao lado da palavra "intelectuais" para que, quase de imediato, apareça diante de nossos olhos uma biblioteca inteira de estudos sobre eles, bastante intimidante em sua amplitude e minuciosamente focada em seus detalhes. Além dos milhares diferentes estudos históricos e sociológicos de intelectuais, há também intermináveis relatos sobre os intelectuais e o nacionalismo, e o poder, e a tradição, e a revolução, e por aí afora. Cada região do mundo produziu seus intelectuais, cada uma dessas formações é rebatida e argumentada com uma paixão ardente. Não houve nenhuma grande revolução na história moderna sem intelectuais; de modo inverso, não houve nenhum grande movimento contrarrevolucionário sem intelectuais. Os intelectuais têm sido os pais e as mães dos movimentos e, é claro, filhos e filhas e até sobrinhos e sobrinhas. (SAID, 2005, p. 25)

Para o presente trabalho, a denominação "intelectual" será utilizada para se referir àqueles que refletiram sobre sua própria condição e a realidade histórica em que viviam, divulgando essa reflexão para que ela pudesse ser discutida e polemizada. Mais do que a transformação e a movimentação, a intenção aqui é estudar a reflexão sobre a identidade e a História.

O mesmo García Márquez que entregou a cidade de sua criação às formigas devoradoras, em um prefácio para sua coletânea Doze contos peregrinos, nos dá um exemplo desse tipo de reflexão, ao comentar sobre a exploração de sua identidade de latinoamericano:

Revista Eletrônica da ANPHLAC, n.13, p. 227-250, jul./dez. 2012. http://revista.anphlac.org.br/index.php/revista 
A primeira idéia me ocorreu no começo da década de setenta, a propósito de um sonho esclarecedor que tive depois de estar há cinco anos morando em Barcelona. Sonhei que assistia ao meu próprio enterro, a pé, caminhando entre um grupo de amigos vestidos de luto solene, mas num clima de festa. Todos pareciam felizes por estarmos juntos. E eu mais que ninguém, por aquela grata oportunidade que a morte me dava de estar com meus amigos da América Latina, os mais antigos, os mais queridos, os que eu não via fazia tempo. Ao final da cerimônia, quando começaram a ir embora, tentei acompanhá-los, mas um deles me fez ver com uma severidade terminante que, para mim, a festa havia acabado. "Você é o único que não pode ir embora", me disse. Só então compreendi que morrer é não estar nunca mais com os amigos. Não sei por que, interpretei aquele sonho exemplar como uma tomada de consciência da minha identidade, e pensei que era um bom ponto de partida para escrever sobre as coisas estranhas que acontecem aos latino-americanos na Europa. (MÁRQUEZ, 1992, p. 4)

A associação entre a morte, a separação definitiva entre um indivíduo e as pessoas que lhe são caras, com a descoberta de uma identidade, de um caráter presente nesse mesmo indivíduo, surge como um gérmen para a exploração do estranhamento sentido pelos latino-americanos em ambiente estrangeiro. Essa colisão cultural engloba desde o choque de comportamentos, posições políticas e religiosas, até a amargura do exílio e da exclusão, do sentimento de ser componente de uma humanidade particular, no sentido bolivariano ${ }^{5}$ do termo (BOLÍVAR, 1984, p. 25). A personagem do sonho, Gabriel García Márquez, descobre-se latino-americano por estar junto de seus amigos e por saber da impossibilidade de revê-los. Os personagens dos doze contos, que se seguirão ao prefácio citado, demonstram sua identidade por estarem em ambiente estranho, muitas vezes hostil, e por estarem longe de seu país, amigos e família, longe de seu ambiente de origem e de formação. Assim, a identidade vem à tona com o distanciamento e a perspectiva de ausência, com um choque que desperta nesses latino-americanos o pensamento de possuírem um caráter único, complexo e surpreendente e que seja suficiente para estabelecer uma contraposição com os europeus.

Esse encontro com a identidade, tão fortemente descrita pelas liberdades poéticas e estéticas da literatura ficcional, é proveniente de uma busca e exploração do significado de

\footnotetext{
${ }^{5}$ García Márquez, em seu romance $O$ general em seu labirinto, realizou um trabalho de reflexão histórica e política sobre o significado da figura de Simon Bolívar. Um dos assuntos abordados na obra é justamente a condição de particularidade dos habitantes dos países americanos, contada por meio de uma narrativa sobre os últimos dias da vida de Bolívar. O texto traz uma visão melancólica e pessimista sobre as tentativas de criar um continente pan-americano. Para o Bolívar presente nas páginas de García Márquez, suas tentativas de unificação foram frustradas, principalmente no sentido de aproximar as Américas da Europa colonizadora.
}

Revista Eletrônica da ANPHLAC, n.13, p. 227-250, jul./dez. 2012. http://revista.anphlac.org.br/index.php/revista 
ser americano. E essa busca identitária é uma atitude que remonta a autores precedentes, que escreveram no final do século XIX, utilizando estilos literários como o ensaio e a poesia. Uma parte desses autores estava vinculada a um movimento literário conhecido como a "Geração Hispano-Americana de 98". Porém, antes de abordar com mais detalhes os autores e escritos da "Geração de 98", é necessário destacar um detalhe na forma como os pertencentes a esse grupo encaravam a identidade americana. Enquanto as obras de autores do século XX, como García Márquez e Júlio Cortazar, abordam o estranhamento e a particularidade do caráter latino-americano, os escritores de fins do século XIX propõem um modelo identitário para a América hispânica. Esse modelo seria construído tendo como base a Europa. Consequentemente, o pensamento desses intelectuais do século XIX, ao invés de ressaltar o choque cultural entre aqueles que um dia foram colonizador e colonizado, busca fazer aflorar as características consideradas elevadas e ideais. Por sua vez, essas características são exemplificadas por elementos da cultura europeia. Nas ideias dos intelectuais hispano-americanos da "Geração de 98", existe a noção de que os valores professados pela parte latina da Europa ${ }^{6}$ deveriam ser adotados como uma espécie de chave universal para o desenvolvimento de todos os povos. A proposta de constituição identitária estava ligada às semelhanças com a Europa, e não com o estranhamento e a diferença expressos por García Márquez. Por mais falha e equivocada que seja essa noção, ela nos permite entender mais profundamente o pensamento desse grupo de intelectuais, e a forma como sua ideias dialogavam com a história da América e com o momento histórico em que estiveram ativos.

\footnotetext{
${ }^{6}$ A parte latina da Europa é vista por esses autores como uma continuidade da cultura do Império Romano. A América teria o dever, portanto, de levar adiante a tradição iniciada na Antiguidade. De certa forma, o continente é visto como o herdeiro da missão de Eneias, que é levar a memória de seus ancestrais para um novo território. A viagem de Eneias, segundo a poesia de Virgílio, terminou com a fundação das bases para a cidade de Roma. E Roma, por sua vez, deixou como herança sua cultura e as línguas derivadas do latim. Os países europeus latinos, como a França, a Espanha e Portugal, vieram então para a América, dando continuidade à jornada de Eneias, contada pelos versos de Virgílio: "Canto os combates e o herói que, por primeiro, fugindo do destino, veio das plagas de Troia, para a Itália e para as praias de Lavínio. Longo tempo foi o joguete, sobre a terra e sobre o mar, do poder dos deuses superiores, por causa da ira da cruel Juno; durante muito tempo, também sofreu os males da guerra, antes de fundar uma cidade e de transportar seus deuses para o Lácio: daí surgiu a raça latina e os pais albanos e as muralhas da soberba Roma" (VIRGÍLIO, 2003, p. 9).
}

Revista Eletrônica da ANPHLAC, n.13, p. 227-250, jul./dez. 2012. http://revista.anphlac.org.br/index.php/revista 
É importante não generalizar autores e movimentos em blocos ideológicos, ignorando suas diferenças e particularidades. Portanto, para os propósitos de estudo deste artigo, serão abordadas as ideias de um dos autores pertencentes à "Geração de 98", relacionando-as com os propósitos expressos pelo movimento e com o projeto identitário desenvolvido por essa comunidade de autores. O autor em questão é o uruguaio José Enrique Rodó ${ }^{7}$, autor de obras como Ariel, Motivos de Proteo e O mirante de Próspero. Recorre-se à obra de Rodó como exemplo e como fonte de estudo, principalmente pelo fato de o autor uruguaio ter sido um porta-voz do pensamento idealista da América hispânica no final do século XIX.

Primeiramente, convém fazer uma exposição sobre a "Geração de 98" e o contexto histórico-literário do qual o movimento fez parte, o chamado "Modernismo HispanoAmericano". Ao mesmo tempo em que diversos autores americanos se engajavam nessa tendência literária, um grupo de intelectuais espanhóis propunha projetos semelhantes, tanto no campo da política quanto no da cultura. Essa convergência de interesses possibilitou um diálogo intelectual entre a Europa e a América (BERNECKER, 2000, p. 38), marcado profundamente por um acontecimento ocorrido no ano de 1898, a Guerra Hispano-Americana. Esse conflito foi um marco decisivo para o delineamento de projetos para a constituição identitária dos países americanos, dando origem a discussões e a adoções de símbolos e modelos.

As questões que devemos desenvolver dizem respeito às características contidas dentro do modernismo hispânico e hispano-americano, que nos permitem entender sua relação com a Guerra Hispano-Americana. Outro desenvolvimento pertinente é o questionamento das razões que levam uma parte de toda essa diversidade de literatos modernistas serem reunidos sob a denominação de "Geração de 98". O que constituiria o conceito de geração? No mínimo, pode-se dizer que, para determinado autor declarar que

\footnotetext{
${ }^{7}$ José Enrique Rodó (1872-1917): filósofo, jornalista e ensaísta uruguaio, defensor de uma cultura hispanoamericana idealista, em oposição ao materialismo representado pelos Estados Unidos. Esses princípios foram delineados em sua obra principal, o ensaio Ariel, de 1900. Ao longo de sua vida e obra, Rodó continuou a defesa dos princípios idealistas, por meio de sua participação do movimento literário modernista e também pelo engajamento partidário, tendo sido filiado ao Partido Colorado. Outras obras: Motivos de Proteo (1908) e El mirador de Próspero (1913).
}

Revista Eletrônica da ANPHLAC, n.13, p. 227-250, jul./dez. 2012. http://revista.anphlac.org.br/index.php/revista 
pertence a uma geração literária, é necessário que ele encontre entre os demais pertencentes do grupo uma proposta e um objetivo comuns, e também uma semelhança em seus ideais estéticos. No caso da "Geração de 98", essas semelhanças se encontram no projeto identitário para o continente americano e nos modelos e símbolos escolhidos para a construção e a propagação desse projeto, além das opções estéticas ligadas ao modernismo.

No referente a essas propostas estéticas, podemos encontrar uma vontade de rompimento com as formas literárias desenvolvidas e consagradas ao longo do século XIX, principalmente a literatura cientificista, e extremamente calcada nos aspectos materiais da existência. Nos demais movimentos literários modernistas, como os ocorridos no Brasil ou nos países de língua inglesa ${ }^{8}$, o que predominou foi exatamente esse rompimento com formas cristalizadas de se escrever, o que, em algumas ocasiões, desembocou em uma radicalização linguística e formal. O movimento brasileiro, que teve como ponto inicial a Semana de Arte Moderna de 1922, defendeu tanto novas formas de utilização da linguagem quanto a abordagem de temas nacionais, mostrando o viés político do movimento. Os autores de língua inglesa, como o irlandês James Joyce $^{9}$ ou o estadunidense William Faulkner $^{10}$, para citar apenas alguns, investem em uma exploração extrema das fronteiras da

\footnotetext{
${ }^{8}$ Interessante notar que obras modernistas brasileiras e em língua inglesa, como Macunaíma (1928), de Mário de Andrade; Ulisses (1922), de James Joyce e $O$ som e a fúria (1929), de William Faulkner, foram publicadas no século XX, em um período posterior ao ápice do movimento modernista hispano-americano. Esse fato reforça as diferenças fundamentais entre esses movimentos literários citados, que, apesar de mostrarem características semelhantes, como a exploração da identidade cultural de uma nação, diferem em aspectos como o uso da linguagem. Um livro como Macunaíma, por exemplo, utiliza uma mistura de formas linguísticas e procura o caráter da população brasileira através da exploração de lendas e de tradições populares. $\mathrm{O}$ enfoque na expressão popular e na linguagem coloquial - que também está presente nos livros de Joyce e de Faulkner citados - não está presente no modernismo hispano-americano, que expressa uma tendência aristocrática no que se refere aos temas tratados por suas obras e ao preciosismo linguístico adotado para tratá-los.

${ }^{9}$ James Augustine Aloysius Joyce (1882-1941): escritor irlandês, um dos mais influentes autores do século XX, pioneiro no uso do chamado fluxo de consciência em seus romances e protagonista de uma revolução formal na ficção literária. Publicou o conjunto de contos Dublinenses (1914), o romance semiautobiográfico Retrato do artista quando jovem (1916), Ulisses (1922) e Finnegans Wake (1939), no qual demonstra uma radicalização de sua inventividade linguística.

10 William Cuthbert Faulkner (1897-1962): escritor estadunidense, famoso por seu experimentalismo estilístico e pela abordagem dos conflitos existentes no sul dos Estados Unidos. Grande parte de suas obras se passa em uma região fíctícia, denominada Yoknapatawpha County, que funciona como uma espécie de amálgama dos estados sulistas norte-americanos. Faulkner escreveu contos, romances, poesias, peças e roteiros para cinema, tendo recebido o prêmio Nobel de Literatura no ano de 1949. Entre suas obras mais
}

Revista Eletrônica da ANPHLAC, n.13, p. 227-250, jul./dez. 2012. http://revista.anphlac.org.br/index.php/revista 
própria língua, fundindo o erudito com o coloquial, e abrindo formas de se explorar o caráter e a psicologia de um povo por meio da literatura. Já no modernismo hispanoamericano, os experimentalismos linguísticos são menos radicais, mas seus autores apresentam um cuidado extremo com a linguagem, já que é por meio dela que se dirigem a seu público leitor. E, em comparação com as outras experiências modernistas citadas, podemos encontrar também nos autores hispano-americanos um verniz político e identitário, uma proposta de exprimir, em seus escritos, o caráter dos povos americanos. Seja em seus ensaios, poesias ou romances, os modernistas hispano-americanos buscavam a afirmação dessa identidade, além da declaração de seus projetos e intenções para o continente. Nesse ponto, se encontra a "Geração de 98", que, em sua literatura, investiu na divulgação da ideia de que a identidade americana será encontrada na adoção de modelos externos considerados benéficos.

O seguinte trecho de Javier Ordiz explora a proposta de ruptura do modernismo com as gerações anteriores, no que se refere ao campo político, não ao literário:

El pensamiento modernista representa en primer lugar una clara ruptura con el de las generaciones precedentes, que desde la Independencia habían apoyado de forma entusiasta la llegada a su territorio de lo que consideraban influencia benefactora de las potencias europeas que, en su opinión, habían de traer a sus naciones emergentes el progreso y la prosperidad del Viejo Mundo. Junto con el capital, entraron en estos años en el continente modas, costumbres, ideas y leyes que, lejos de ser rechazadas se consideraron agentes activos de una civilización llamada a desterrar a la barbarie ancestral del ser americano. (ORDIZ, 2004, p.1)

O citado pensamento modernista começava a delinear, então, as influências externas a serem evitadas. E, com a conclusão da Guerra Hispano-Americana, em 1898, essas ideias se tornaram ainda mais claras, ganhando uma força única até então, encontrada nos escritos da "Geração Hispano-Americana de 98". A influência a ser evitada seria representada pela potência americana, os Estados Unidos da América, enquanto as interferências europeias eram consideradas bem-vindas, como destaca o texto de Ordiz. E, da mesma forma que anteriormente os países europeus encontravam-se presentes na América, fosse industrial ou culturalmente. No momento do final do século, essa presença se devia predominantemente

importantes e conhecidas, estão os romances $O$ som e a fúria (1929), Enquanto agonizo (1930) e Luz em agosto (1932).

Revista Eletrônica da ANPHLAC, n.13, p. 227-250, jul./dez. 2012. http://revista.anphlac.org.br/index.php/revista 
aos Estados Unidos. O apoio dos EUA à independência de Cuba, conquistada após o fím da Guerra Hispano-Americana, simboliza essa troca de influências. A potência americana derrotou, através das armas e da cultura, potências europeias como a Espanha colonizadora. E a "Geração de 98" revoltou-se contra essa derrota, que considerava um dos perigos a serem evitados pela América independente.

O ano de 1898 possui uma grande importância, sendo um momento que reuniu acontecimentos históricos e reações a eles. Reações essas que uniram, por meio de ideias e engajamentos comuns, diversos autores, formando a chamada "Geração de 98". Ao explorar os projetos de formação de um discurso que seria capaz de abarcar toda a literatura latino-americana, Ángel Rama defende que esse projeto teria como ponto central algum ponto de comparação com eventos europeus. Esses eventos não seriam referentes a acontecimentos literários, mas sim histórico-culturais. Rama estabelece, a partir dessa ideia, quatro momentos históricos europeus que trouxeram influência profunda sobre a formação de discursos identitários e culturais para a América. Três deles são constantemente citados: o Descobrimento, o Renascimento e a Revolução Francesa. Já o quarto momento diz respeito exatamente ao final do século XIX, período em que alguns autores modernistas hispano-americanos formaram a "Geração de 98":

A partir desses três grandes momentos situamos um quarto, derivado da presença francesa e italiana no último quartel do século 19, quando os países americanos se integram aos mercados econômicos internacionais e recebem a avalanche imigratória europeia, num processo constante que se estende até boa parte do século 20, sem que a crescente influência norte-americana, desde sua expansão imperial em 1898, tenha conseguido contrabalançar até épocas mais recentes. Se nos ativéssemos somente a este traço de "romanidade" ou "latinidade", talvez fosse possível encarar o projeto de reintegração de todos os seus setores. No entanto, existem notórias diferenças entre o setor europeu (forjador da romanidade) e o setor americano (que herda a romanidade e a traslada a um âmbito diferente, promovendo sua miscigenação com todo tipo de correntes autóctones ou importadas), que ocorrem através do processo de colonização, tanto a original, político-militar, como a posterior, de natureza econômica e financeira, que a substitui a partir da independência política, sendo ambas portadoras de estruturas culturais.(RAMA, 2008, p. 139)

É notável o destaque que Ángel Rama dedica ao ano de 1898, situado como o momento da expansão imperial dos Estados Unidos. Além dessa presença imigratória e econômica, os países americanos do final do século XIX estiveram sob a influência de duas

Revista Eletrônica da ANPHLAC, n.13, p. 227-250, jul./dez. 2012. http://revista.anphlac.org.br/index.php/revista 
tendências culturais, a norte-americana e a europeia. Como terceiro fator, existe a cultura da América hispânica, claramente herdeira dos elementos culturais legados pela parte latina da Europa, mas que não pode ser considerada uma simples derivação eurocêntrica. Nesse sentido, Rama estabelece o conceito de "romanidade" e de "latinidade". De um lado, está a cultura deixada pelo Império Romano, representada pelas línguas derivadas do latim; de outro, está a cultura formada nos países colonizados por esses herdeiros do Império Romano, ou seja, pelos países latinos da Europa. E é na valorização do legado europeu, juntamente com a formação consciente de uma cultura própria da parte latina da América, que se encontram os projetos para a formação de uma identidade americana. Os projetos também se utilizam de modelos, para exemplificar sua prédica, dizendo qual tipo de influência cultural deve ser aceita e qual rejeitada. Os autores da "Geração de 98" defendiam veementemente a aceitação do modelo europeu de cultura, política e economia e recusavam a influência estadunidense, que se apresentou ostensivamente no ano de 1898, com a Guerra Hispano-Americana.

Antes de se aprofundar no pensamento identitário da "Geração de 98", é conveniente explorar tanto o acontecimento histórico - a Guerra Hispano-Americana - e as teorias políticas representadas por ele - como a Doutrina Monroe -, de modo a estabelecer os parâmetros que levaram os autores modernistas a tomar sua posição em meio a esse debate político e cultural.

A Guerra Hispano-Americana marcou o ano de 1898 e resultou na independência da ilha de Cuba. Em sua luta armada para alcançar a independência da Espanha, os cubanos tiveram auxílio militar dos Estados Unidos, que gradativamente firmavam seu status de potência mundial. Dessa forma, no mesmo momento em que a ilha deixava de ser colônia, separando-se de uma dependência que datava desde os anos da colonização, entrava em outro laço de dependência, dessa vez política e econômica, em relação aos Estados Unidos. Além da interferência estadunidense no conflito armado, houve também uma grande influência no processo de pós-independência, que deu origem à Emenda Platt, parte integrante da constituição de Cuba independente, e à instalação de uma base militar norteamericana em território cubano, a base de Guantánamo. A Emenda Platt é um símbolo claro

Revista Eletrônica da ANPHLAC, n.13, p. 227-250, jul./dez. 2012. http://revista.anphlac.org.br/index.php/revista 
do constante aumento da interferência dos Estados Unidos em assuntos de política exterior, já que permitia ao país intervir militarmente em Cuba, caso seu governo julgasse necessário. Esses indícios do imperialismo norte-americano, que podem ser entrevistos ao se analisar os eventos que compuseram a Guerra Hispano-Americana, surgem como uma espécie de concretização da Doutrina Monroe, teoria presente nos discursos políticos desde o ano de 1823 (ORDIZ, 2004, p.1-2). E reações contra a interferência estadunidense apareceram, algumas já presentes no ambiente político e intelectual hispano-americano anteriormente à Guerra Hispano-Americana.

Antes da formação da "Geração Hispano-Americana de 98", autores modernistas como o nicaraguense Rubén Darío ${ }^{11}$ e o cubano José Martí ${ }^{12}$ levantavam questionamentos sobre o crescente papel dos Estados Unidos na política e na economia do restante da América, utilizando-se de uma poesia engajada e inflamada. Além da poesia, os dois autores se exercitaram na literatura ensaística. Darío publicou, no jornal El Tiempo, de Buenos Aires, em 1898, o artigo "El triunfo de Calibán", rechaço violento não somente à política estadunidense, mas à sua cultura e a seus costumes. O artigo teve uma importância fundamental para a formação do pensamento de José Enrique Rodó e de seu ensaio Ariel (1900), assunto que será explorado mais adiante. Quanto a José Martí, foi o autor de outro célebre ensaio, um dos mais discutidos no que se refere à proposição de uma identidade americana: Nuestra América, publicado em 1891. Martí foi um dos combatentes na luta pela independência de Cuba, tendo sido morto em combate no ano de 1895. Essa morte, juntamente com seu engajamento, o fez ser valorizado como mártir, pelos seus

11 Felix Rubén García Sarmiento, conhecido como Rubén Darío (1867-1916): poeta nicaraguense, considerado um dos mais importantes da literatura em língua espanhola de sua época, e o grande representante do Modernismo literário hispânico. Expressando suas teorias políticas e culturais em sua obra poética e em seus ensaios, marcou profundamente seus contemporâneos modernistas e movimentos literários posteriores. Foi o primeiro autor hispano-americano a trabalhar com as metáforas da peça A tempestade, de William Shakespeare, utilizando-as como símbolo identitário para a América em seu artigo El triunfo de Calibán". Essa simbolização seria continuada por diversos autores posteriores. Entre outras obras, escreveu Rimas (1887) e Prosas profanas y otros poemas (1896).

12 José Julián Martí Pérez (1853-1895): poeta, ensaísta, jornalista e filósofo cubano, grande defensor da independência de Cuba. Autor do influente ensaio Nuestra América (1891) e um dos nomes mais importantes da literatura em língua espanhola, foi morto em ação contra os espanhóis, em um conflito do qual havia sido um dos grandes defensores. Tornou-se assim um símbolo da luta pela emancipação cubana, não somente pelos seus escritos, mas pela sua atuação na política e no movimento armado pela independência.

Revista Eletrônica da ANPHLAC, n.13, p. 227-250, jul./dez. 2012. http://revista.anphlac.org.br/index.php/revista 
contemporâneos e por diversos autores que escreveram posteriormente. Esse poeta, que ficou marcado na História das Américas como um dos mártires da independência cubana, deixou versos contra a tirania e a exploração capitalista:

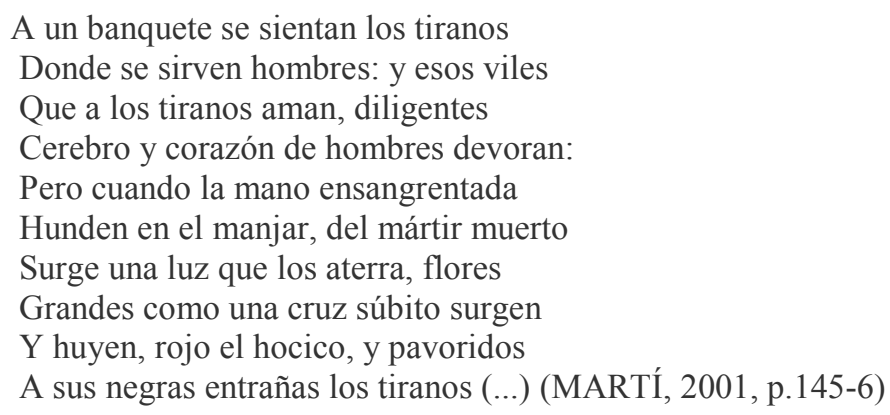

Essas atitudes, consideradas tirânicas e cruéis, podem ser associadas, no pensamento de Martí, às atitudes dos Estados Unidos, no concernente à política externa e à constante exploração da indústria no país. E foi o país desaprovado por Martí que desempenhou papel fundamental na independência cubana, terra natal do poeta. Nesse ambiente de proposições conflitantes, onde o ambiente político e econômico indicava um aumento exponencial da influência estadunidense, e onde intelectuais defendiam a negação dessa mesma influência e a busca por um modelo de identidade legado pela Europa, um projeto para a América era divulgado. Esse projeto, desenvolvido em parte pelos autores da "Geração de 98" e, mais destacadamente, por José Enrique Rodó, era o projeto de uma América arielista.

O termo arielista é derivado de Ariel, personagem da peça A tempestade, de William Shakespeare. A peça, um dos últimos - ou o último ${ }^{13}$ - trabalho do dramaturgo inglês, moveu um grande número de interpretações entre autores europeus e americanos. Entre os europeus, o mais destacado é o humanista Ernest Renan ${ }^{14}$, que escreveu uma sequência da peça de Shakespeare, intitulada Caliban: suîte de "La tempête". A obra de Renan foi importante na composição do ensaio Ariel, de Rodó, sendo que o autor é

${ }^{13}$ Dentre as diversas peças e poemas presentes nas obras de William Shakespeare, considera-se que $A$ tempestade é a última das peças escritas sem colaboração, já que obras como Henrique VIII e The two noble kinsmen possuem marcas de estilo que indicam a interferência - ou colaboração de outro autor, provavelmente John Fletcher (BLOOM, 2000, p.662).

14 Joseph-Ernest Renan (1823-1892): filólogo, filósofo e historiador francês, grande propagador do cientificismo. Em A vida de Jesus (1863), provocou polêmicas, ao questionar a divindade de Jesus Cristo, e iniciou uma série de livros dedicados à análise das raízes do cristianismo. Outra de suas obras importantes é $O$ futuro da ciência (1890).

Revista Eletrônica da ANPHLAC, n.13, p. 227-250, jul./dez. 2012. http://revista.anphlac.org.br/index.php/revista 
constantemente citado nos escritos do autor uruguaio. Ao imaginar uma continuação dos eventos criados por Shakespeare na peça original, Renan defende suas teorias aristocráticas de governo, afirmando que a forma ideal de organização política seria um governo de sábios, excluindo dos negócios públicos a maior parte da população (RENAN, 1878, p.91). As teorias de Renan ecoam profundamente na obra de Rodó, principalmente em seus escritos do final de século XIX, momento em que o autor formava sua tese da existência de um americanismo cultural (AACHEN, 1999, p.141-3). Outra obra importante no pensamento de Rodó foi o já citado artigo de Rubén Darío, “El triunfo de Calibán”, que expõe uma proposta de identificação da América com suas origens europeias, além de defender violentamente o rechaço das crescentes influências norte-americanas, rotulando-as como bárbaras. No texto de Darío e, dois anos depois, no Ariel de Rodó, os modelos de projetos identitários para o continente são simbolizados por duas personagens de Shakespeare: Ariel e Calibã.

Para o melhor entendimento das interpretações americanas das personagens shakespearianas, é necessário voltar à obra do dramaturgo inglês e buscar quem são Ariel e Calibã. As duas personagens são escravas de Próspero, um duque milanês exilado em uma ilha. Afastado da política para se dedicar aos estudos de artes obscuras, Próspero é deposto pelo irmão, sendo forçado a fugir. Desembarcando na ilha que é cenário da peça, o exduque encontra seus dois habitantes originais, que são exatamente os citados Ariel e Calibã. Ambos tornam-se escravos de Próspero, após o milanês tomar posse do território, utilizando seus conhecimentos, que lhe conferem poderes mágicos. Porém, a postura adotada pelos dois diante da própria servidão é o que marca as interpretações americanas da obra. Ariel é um ser etéreo, sem forma definida, que possui poderes mágicos, servindo Próspero de maneira submissa, à espera de uma eventual libertação, que é concedida ao final do enredo. Calibã, por sua vez, realiza os serviços braçais e sofre castigos físicos por parte do mestre, sendo um escravo revoltado que traça planos contra Próspero. Um fator agravante da revolta de Calibã é o fato de ser filho da bruxa argelina Sycorax, que dominou a ilha antes da chegada de Próspero, tendo deixado o território para seu filho, após sua morte. Essa questão da tomada do território pertencente ao habitante original - Calibã

Revista Eletrônica da ANPHLAC, n.13, p. 227-250, jul./dez. 2012. http://revista.anphlac.org.br/index.php/revista 
nasceu na ilha - fez com que diversos intérpretes da obra a identificassem com a situação do indígena americano (VAUGHAN \& VAUGHAN, 1991, p.155). Porém, essa é uma leitura muito mais ligada às ideias e projetos de quem a realizou do que ao pensamento do próprio Shakespeare. E a maioria das interpretações da peça relacionadas com a América seguem esse caminho.

Já que a intenção aqui não é se aprofundar no pensamento e na literatura shakespeariana, mas sim entender a simbolização realizada com base na obra do dramaturgo, convém se concentrar na forma como o dramaturgo descreveu e utilizou as personagens que se tornariam símbolos para a América. E, nesse sentido, percebe-se que Ariel é um ser espiritual, mágico, enquanto Calibã é um ser tosco e disforme. Ariel serve pacientemente, mesmo desejando, de forma intensa, sua liberdade, pois prefere seduzir seu mestre por meio de um bom comportamento do que atingir sua libertação através da revolta. E é esse modelo de comportamento que será proposto para a América por Rodó e pelos autores da "Geração de 98", os intelectuais que defendiam o projeto de uma América arielista, em oposição à impetuosidade calibanesca, que será associada com os Estados Unidos e com o materialismo.

Esse grupo de autores é, portanto, adepto de uma interpretação idealista da história, da filosofia e dos valores constituintes de uma identidade hispano-americana. Os fundamentos dessa interpretação podem ser identificados, ao se realizar um estudo do ensaio Ariel, de Rodó, verdadeiro manifesto das teorias identitárias idealistas expressas pelos intelectuais da “Geração de 98”. Em seu texto, Rodó descreve as características que julga positivas na cultura e na política europeias, propondo esses valores como um modelo para a constituição identitária da América. Associa, portanto, a Europa com Próspero, o duque exilado da peça de Shakespeare. Seguindo essa lógica, o futuro da América, para o autor, encontrar-se-ia em um destino de Ariel, ou seja, em uma servidão obediente, que seria encerrada com uma independência pacífica. A América deveria ser Ariel e se afastar completamente do rebelde Calibã, que, no pensamento de Rodo, é identificado com o materialismo expresso pelos Estados Unidos e seu desenvolvimento industrial. O ensaio mistura diversos elementos literários, possuindo trechos de ensaio filosófico, de ensaio

Revista Eletrônica da ANPHLAC, n.13, p. 227-250, jul./dez. 2012. http://revista.anphlac.org.br/index.php/revista 
político e até de narrativa ficcional, surgindo como uma expressão ideológica e formal das ideias do modernismo literário hispano-americano. Um exemplo desse estilo pode ser encontrado na introdução da obra:

Aquella tarde, el viejo y venerado maestro, a quien solían llamar Próspero, por alusión al sabio mago de La Tempestad shakesperiana, se despedía de sus jóvenes discípulos, pasado un año de tareas, congregándolos una vez más a su alrededor.

Ya habían llegado ellos a la amplia sala de estudios, en la que un gusto delicado y severo esmerabas por todas partes en honrar la noble presencia de los libros, fieles compañeros de Próspero. Dominaba en la sala - como numen de un ambiente sereno - un bronce primoroso, que figuraba al ARIEL de $L a$ Tempestad. Junto a este bronce se sentaba habitualmente el maestro, y por ello le llamaban con el nombre del mago a quien sirve y favorece en el drama el fantástico personaje que había interpretado el escultor. Quizá en su enseñanza y su carácter había, para el nombre, una razón y un sentido más profundos.

Ariel, genio del aire, representa, en el simbolismo de la obra de Shakespeare, la parte noble y alada del espíritu. Ariel es el imperio de la razón y el sentimiento sobre los bajos estímulos de la irracionalidad; es el entusiasmo generoso, el móvil alto y desinteresado en la acción, la espiritualidad de la cultura, la vivacidad y la gracia de la inteligencia; el término ideal a que asciende la selección humana, rectificando en el hombre superior los tenaces vestigios de Calibán, símbolo de sensualidad y torpeza, con el cincel perseverante de la vida. (RODÓ, 1991, p.3940)

O velho mestre, ensinando aos discípulos, é chamado de Próspero e representa todo o conhecimento e a história da Europa. Ao identificar sua personagem com a de Shakespeare, colocando-a em uma posição de professor, Rodó mostra seu ideal de Europa, o Velho Mundo, ensinando aos seus discípulos, os países independentes do Novo Mundo. Porém, considera que essa independência é algo relativamente recente, formando a imagem de uma América em aprendizado. Aprendizado dos valores que formariam a própria cultura, e, consequentemente, formadores de uma identidade hispano-americana.

Juntamente com o ideal de identidade, vem o ideal de nação e de Estado, montando o projeto para o desenvolvimento de um conjunto de países independentes. Esse projeto compreende uma teoria teleológica da civilização. Utilizar o termo teleologia implica dizer que o pensamento rodoniano, ao menos em parte, compreende uma crença no desenvolvimento constante e progressivo de algo. O objeto desse desenvolvimento seria o que o autor entende como civilização, um complexo de relações culturais e políticas, deixando um pouco de lado a dimensão econômica.

Revista Eletrônica da ANPHLAC, n.13, p. 227-250, jul./dez. 2012. http://revista.anphlac.org.br/index.php/revista 
Normalmente, o desenvolvimento de um país, ou de um conjunto deles, acaba sendo associado com a industrialização e o crescimento econômico. Por isso, é fundamental frisar a posição de Rodó diante do desenvolvimento industrial. O autor uruguaio não desaprovava inteiramente o fortalecimento econômico dos países hispano-americanos, mas se posicionava contrariamente ao que enxergava como um abandono de valores, como a razão e a erudição, para dar lugar a uma ambição e a uma ganância desenfreadas. A prédica de Rodó fundamenta-se, principalmente, na evocação de um idealismo ${ }^{15}$, em oposição ao materialismo utilitário, que ganhava força com o imperialismo estadunidense. Os valores idealistas trariam um cultivo do espírito humano, por meio de atividades reflexivas como o debate intelectual, criando um ambiente que se preocupa não apenas com a situação presente da América, mas também com os rumos que serão seguidos pelo continente. O materialismo implicaria uma fixação com o presente, provocando um individualismo e um conflito de interesses constante entre os homens.

Esse fundamento do pensamento rodoniano - e de boa parte dos autores modernistas hispano-americanos - nos permite entrever uma filosofia cultural e política extremamente exclusivista. Ao mesmo tempo em que Rodó deseja a extensão dos valores idealistas ao maior número de pessoas possível, o autor estabelece uma linha divisória entre aqueles que seguirão esses valores e aqueles que adotarão o materialismo. Os primeiros cultivariam seu "espírito", explorariam os valores constituintes da própria humanidade. Já os segundos teriam as possibilidades de crescimento intelectual abortadas, embotando sua inteligência e suas possibilidades de convivência com os demais seres humanos (RODÓ, 1991, p.60). O seguinte trecho de Ariel estabelece um curioso debate entre os conceitos de aristocracia e de democracia, apresentando a ideia de superioridade intelectual:

Racionalmente concebida, la democracia admite siempre un imprescriptible elemento aristocrático, que consiste en establecer la superioridad de los mejores, asegurándola sobre el consentimiento libre de los asociados. Ella consagra, como

\footnotetext{
${ }^{15}$ Por idealismo, entendo uma concepção filosófica cujo centro é encontrado no plano das ideias, em oposição a uma opção de entendimento de mundo calcada no material e nos atos concretos. Rodó e outros autores contemporâneos a ele seguem, portanto, uma interpretação filosófica centrada no imaterial, no idealista, sendo continuadores de uma filosofia que remonta à Antiguidade e a pensadores como Platão. E, ao mesmo tempo em que se inserem nessa tradição filosófica, os autores abordados no presente artigo retomam esses enunciados discursivos filosóficos, acrescentando peculiaridades próprias à sua época e ao local do qual falam.
}

Revista Eletrônica da ANPHLAC, n.13, p. 227-250, jul./dez. 2012. http://revista.anphlac.org.br/index.php/revista 
las aristocracias, la distinción de calidad; pero las resuelve a favor de las calidades realmente superiores - las de la virtud, el caráter, el espíritu - , sin pretender inmovilizarlas en clases constituidas aparte de las otras, que mantengan a su favor el privilegio execrable de la casta, renueva sin cesar su aristocracia dirigente en las fuentes vivas del pueblo y la hace aceptar por la justicia y el amor. (RODÓ, 1991, p. 102-3)

Outra ideia ligada a essa democracia aristocrática é a recuperação do conceito grego de ócio, que pode ser associada com o pensamento platônico expresso em obras como $A$ república e $O$ banquete. Essa recuperação de temas, ideias e imagens da Antiguidade Clássica encontram-se presentes no pensamento modernista da época. Porém, mais do que uma simples evocação, esses autores ressignificam ${ }^{16}$ o legado da Antiguidade, assim como reinterpretam obras produzidas em contexto europeu, caso da peça de Shakespeare.

Voltando à interpretação que Rodó realizou da obra shakespeariana, encontramos uma simbolização do que o uruguaio acreditava ser a identidade americana. Mesmo não utilizando a palavra identidade, Rodó discute as possibilidades para um processo de reconhecimento e adoção de um futuro para os povos americanos. E pode-se dizer que, de acordo com o caminho escolhido, a América poderia encontrar ou não seu verdadeiro caráter, conceito esse próximo ao que atualmente denominamos identidade. Caso seguisse o modelo de cultura europeia, a América estaria no caminho considerado correto, explorando suas origens e seu caráter. No pensamento de Rodó e dos demais autores da "Geração de 98” existem juízos de valor e uma definição do que seria o verdadeiro e o correto. Dessa forma, no manifesto das ideias dos integrantes desse movimento literário e político - o ensaio Ariel -, os caminhos para o futuro da América são simbolizados exatamente pelas personagens da obra de Shakespeare. A América poderia seguir o rumo de Ariel ou o de Calibã, e as duas personagens tornam-se símbolos para modelos de identificação. E esses modelos constituem, por sua vez, projetos para a constituição da identidade dos países hispano-americanos.

\footnotetext{
${ }^{16}$ Por ressignificação, entende-se o processo de leitura e interpretação de determinada obra, personagem, ou acontecimento, seguido de uma simbolização do objeto interpretado. É uma leitura específica, extremamente dependente das opiniões e posições políticas e ideológicas do autor. Dessa forma, a simbolização provavelmente aparece com algum objetivo direto, vinculado aos projetos de seu autor/criador.
}

Revista Eletrônica da ANPHLAC, n.13, p. 227-250, jul./dez. 2012. http://revista.anphlac.org.br/index.php/revista 
O estudo do ensaio de Rodó nos fornece diversos indícios sobre o momento histórico dos países americanos no final do século XIX, bem como sobre algumas das propostas e engajamentos culturais dos intelectuais da época. A constante prédica rodoniana pela busca de uma América-Ariel funciona como um sumário de várias ideias e discussões presentes entre os autores modernistas da Hispano-América. Seguir os ensinamentos de Próspero - ou da Europa - faria a América tornar-se Ariel, o servo inteligente, mágico, racional e belo, aquele que aguarda com paciência o momento de sua libertação. O outro caminho, o de Calibã, seria o caminho da revolta e da liberdade tomada à força, seguindo o exemplo dos Estados Unidos. A revolta armada, que foi utilizada para a obtenção da independência de Cuba, não encontra lugar no pensamento idealista de Rodó, principalmente porque está ligada à violência e às paixões primitivas, ao invés de sentimentos considerados elevados como a razão e o desenvolvimento intelectual.

Porém, as teorias idealistas carecem, em alguns pontos, de uma certa inserção no ambiente social ao qual pertencem. Por mais que Rodó desaprove a adoção da revolta calibanesca e a aceitação da influência dos Estados Unidos, seu pensamento oferece poucas proposições fortes para a realização do tão ambicionado desenvolvimento do espírito. Em alguns pontos de seus textos, a noção de intelectual e de espírito parece se resumir a um conceito etéreo, que flutua acima da realidade e da história. O intercâmbio de ideias, então, é descrito como uma espécie de novo Monte Parnaso, no qual os intelectuais e artistas debatem em um ponto mais elevado do que o restante da humanidade. Essa visão exclusivista do intelectual acaba por desembocar até mesmo em algumas contradições no pensamento rodoniano, como na já citada democracia aristocrática. A existência de contradições indica também um pensamento que nunca se torna monolítico e unificado, mas sim desfia sua erudição em incontáveis citações e demonstra seu engajamento sem restrições. A demonstração ostensiva desse engajamento não encontra nenhuma barreira em pudores e modelos científicos, já que os trabalhos de Rodó estão inseridos em um estilo ensaístico, possuindo uma liberdade de expressão consideravelmente maior.

Todas essas características, apreendidas com o estudo de Ariel, indicam também uma capacidade de modificação e de adaptação de ideias, que pode ser compreendida ao se

Revista Eletrônica da ANPHLAC, n.13, p. 227-250, jul./dez. 2012. http://revista.anphlac.org.br/index.php/revista 
analisar as demais obras de Rodó, como Motivos de Proteo, de 1909, e O mirante de Próspero (El mirador de Prospero), de 1913. Proteo - ou Proteu - é uma figura mitológica grega, que possui a capacidade de mudar de forma. O encontro do ser mutável com Agamenon é narrado no Canto IV da Odisséia (HOMERO, 2002, p.60-4), e sua semelhança com Ariel é notável. Ambas as personagens não possuem forma definida, são dotadas de poderes mágicos e são astuciosas. E ambas descrevem parte da dinâmica ideológica de Rodó, que utiliza esses símbolos, retirados da literatura e da mitologia, para significar a mutabilidade e a capacidade de adaptação de seu próprio pensamento. Ao dizer que possui motivos de Proteu, Rodó transmite a convicção de que seu engajamento político e seu consequente projeto para a identidade americana nunca se tornarão corpos sólidos no constante fluxo das ideias. Para sobreviver, um pensamento não pode somente utilizar, de maneira adequada, suas influências, mas é necessário que seja objeto de uma constante revisão e atualização.

Analisando a obra do autor uruguaio, portanto, não se encontram somente indícios sobre o momento histórico do final do século XIX e sobre as consequências da Guerra Hispano-Americana. A perspectiva de uma continuidade das discussões travadas entre os intelectuais do período também está presente em seus trabalhos. O mirante de Próspero, por exemplo, utiliza novamente as metáforas retiradas da obra de Shakespeare, para formar a imagem do mestre observando o progresso de seus discípulos ${ }^{17}$. Dessa forma, mesmo após a virada do século, quando a "Geração de 98" não mais se encontrava em pleno intercâmbio de ideias, os princípios defendidos por esses autores continuaram a ser expressos por seu porta-voz, José Enrique Rodó. E foram expressos com as relativizações e atualizações necessárias. Um dos lemas empregados pelo autor uruguaio em seus escritos é particularmente significativo: "reformarse es vivir" (RODÓ, 1993, p.3).

\footnotetext{
${ }^{17}$ O mirante de Próspero influenciou, por sua vez, o trabalho de Richard Morse, que, em seu livro, O espelho de Próspero, explora as relações culturais entre a Anglo-América e a Hispano-América. Além de fazer referência ao título do livro de Rodó, sua tese sobre a cultura americana calca-se no princípio da substituição de um mirante, um ponto de observação, por um espelho, que, ao mesmo tempo, é um ponto de observação e uma forma de refletir sobre si mesmo (MORSE, 2000, p.13-4).
}

Revista Eletrônica da ANPHLAC, n.13, p. 227-250, jul./dez. 2012. http://revista.anphlac.org.br/index.php/revista 
Todos esses intelectuais componentes da "Geração de 98", que partilhavam das ideias de Rodó, podem ser classificados como intelectuais $\operatorname{arielistas}^{18}$, já que pregam o caminho simbolizado por Ariel. Além de Rodó, a lista dos modernistas que se incluem no grupo denominado de "Geração de 98" compreende autores de diferentes nacionalidades e diferentes estilos literários. Os mais significativos são o venezuelano Rufino Blanco Fombona $^{19}$, os argentinos Manuel Ugarte $^{20}$ e José Ingenieros ${ }^{21}$, o peruano José Santos Chocano $^{22}$, o mexicano José Vasconcelos ${ }^{23}$, o dominicano Pedro Henríquez Ureña ${ }^{24}$ e o equatoriano Gonzalo Zaldumbide ${ }^{25}$ (BERNECKER, 2000, p.38-9). É importante notar como uma forma de pensamento comum uniu autores provenientes de países e de realidades tão diversas. Ideias como o rechaço ao imperialismo estadunidense, a valorização do idealismo e do ócio criativo convergem para a formação de uma sociedade de intelectuais, que se unem para a proposição de um projeto identitário para a América. E o termo mais utilizado é exatamente este: América. Ao invés de se referirem a um país específico, recorrem a uma generalização, unindo diversas localidades sob um conceito. Essa generalização, em alguns pontos, é extremamente restritiva, mas serve perfeitamente aos ideais do discurso enunciado por esses intelectuais arielistas.

\footnotetext{
${ }^{18}$ Como já destacado anteriormente, são entendidas por arielistas as leituras da peça calcadas na proposição de um continente modelado em Ariel, se espelhando na Europa. Já as leituras calibanistas são as que propõem uma busca pela identidade americana, calcada na figura de Calibã. Seguindo essa lógica, os intelectuais, que adotam a posição política de proposição de uma identidade americana se espelhando na Europa, podem ser classificados como intelectuais arielistas. Cf. MORALES, 2000, p.95-104.

${ }^{19}$ Rufino Blanco Fombona (1874-1944): escritor e político venezuelano, defensor da formação de uma cultura americana. Suas principais obras são os romances El hombre de hierro (1907), El hombre de oro (1916) e La máscara heroica (1923).

${ }^{20}$ Manuel Baldomero Ugarte (1875-1951): escritor, poeta e político socialista argentino, autor de obras como El porvenir de America Española (1910).

${ }^{21}$ José Ingenieros (1877-1925): psicólogo e filósofo argentino, um dos grandes nomes do positivismo no país e da militância socialista. Autor de obras como La simulación en la lucha por la vida (1903) e La evolución de las ideas argentinas (1918/20).

${ }_{22}$ José Santos Chocano (1875-1934): poeta e ativista político peruano, autor de obras sobre temas indígenas, como Ouro das Índias (1934).

${ }^{23}$ José Vasconcelos (1882-1959): escritor e político mexicano, participante da Revolução Mexicana. É famoso por A raça cósmica (1925).

${ }^{24}$ Pedro Henríquez Ureña (1884-1946): filólogo, crítico literário e escritor dominicano, autor de La utopia de América (1925) e Seis ensayos en busca de nuestra expresión (1928).

${ }^{25}$ Gonzalo Zaldumbide (1883-1965): ensaísta, crítico literário e diplomata equatoriano, autor de Significado de España en América (1933) e Egloga trágica (1962).
}

Revista Eletrônica da ANPHLAC, n.13, p. 227-250, jul./dez. 2012. http://revista.anphlac.org.br/index.php/revista 
Se, no final do século XIX, diversos pensadores expressavam o desejo de ver uma América-Ariel, ao longo do século XX, ocorreria uma mudança conceitual e simbólica. A imagem de Calibã, o escravo revoltado, deixou de ser relacionada com o utilitarismo estadunidense e passou a simbolizar a história dos povos explorados do continente. Um novo projeto identitário surgiu, levado adiante por intelectuais que desejavam a formação de uma América-Calibã, ou seja, um continente consciente de sua história e de sua condição de explorado. É uma interpretação com um viés mais materialista e marxista, que também possui seu manifesto e seu porta-voz, o ensaio Caliban, do cubano Roberto Fernández Retamar ${ }^{26}$, publicado em 1971. A proposta identitária expressa por esse intelectual, que pode ser chamado de calibanista, possui algumas relações com o conceito de estranhamento e particularidade analisado no início do artigo. O que se busca não é a assimilação do legado cultural europeu, mas sim a descoberta de uma cultura e de uma identidade latino-americanas. Porém, mesmo com esse viés ideológico completamente diverso, opondo-se diretamente ao exclusivismo rodoniano, a obra de modernistas como Rubén Darío e Rodó não deixa de ser citada pelos calibanistas (RETAMAR, 2004, p.33-4). Mesmo com os símbolos e metáforas tendo sido ressignificados, a influência dos intelectuais modernistas e da "Geração de 98" é algo marcante para o prosseguimento do debate sobre a identidade americana.

Cada movimento - seja político, cultural ou literário - ou cada autor, possui um projeto identitário, uma forma de se analisar o que significa ser americano. Porém, suas ideias são transmitidas e ecoam em pensamentos contemporâneos ou posteriores, sendo revisadas e também ressignificadas. Dessa forma, tornam-se verdadeiras ideias de Proteu, como defendeu Rodó, ao refletir sobre a dinâmica de formação de seu próprio pensamento (RODÓ, 1912). Ideias, projetos político-identitários e concepções fílosóficas são acontecimentos discursivos, formando cenários movediços - ou protéicos - para a

\footnotetext{
${ }^{26}$ Roberto Fernández Retamar (1930- ): Poeta, ensaísta, crítico literário cubano e um dos principais intelectuais defensores do regime de Fidel Castro. Além de sua poesia, seus trabalhos de maior impacto se referem a estudos culturais sobre a América Latina, como o ensaio Caliban, publicado em 1971, na revista Casa de las Américas. Desde o ano de 1985, é diretor da organização Casa de las Américas, um dos principais órgãos culturais do governo cubano.
}

Revista Eletrônica da ANPHLAC, n.13, p. 227-250, jul./dez. 2012. http://revista.anphlac.org.br/index.php/revista 
interpretação e a representação de determinado local e período. A chave para o estudo desses projetos para a identidade americana é, portanto, a questão da descontinuidade e da retomada e ressignificação do que já foi enunciado. Dessa forma, pode ser construída uma análise que não se restringe somente a um acontecimento central, mas amplia seu alcance, tentando entender o processo de formação do acontecimento em foco.

\section{Referências Bibliográficas}

AACHEN, Marga Graf. En marcha a la sociedad moderna latinoamericana: los cuatro aspectos del americanismo de Rodó. In: ETTE, Ottmar; TITUS, Heydenreich (Org.). José Enrique Rodó y su tiempo: cien años de Ariel. $12^{\circ}$ Coloquio Interdisciplinario de la Seccion Latinoamérica del Instituto Central para Regionales de La Universidad de ErlangenNurnberg. Frankfurt; Madrid: Iberoamericana, 2000. p. 141-152.

ANDRADE, Mário de. Macunaíma: o herói sem nenhum caráter. $32^{\text {a }}$ ed. Rio de Janeiro: Garnier, 2001.

BERNECKER, Walther L. El fin de siglo en el Río de la Plata: intereses internacionales y reacciones latinoamericanas. In: ETTE, Ottmar; TITUS, Heydenreich (Org.). José Enrique Rodó y su tiempo: cien años de Ariel. $12^{\circ}$ Coloquio Interdisciplinario de la Sección Latinoamérica del Instituto Central para Regionales de La Universidad de ErlangenNurnberg. Frankfurt; Madrid: Iberoamericana, 2000. p. 15-39.

BLOOM, Harold. Shakespeare: a invenção do humano. Tradução de José Roberto O'Shea. Rio de Janeiro: Objetiva, 2000.

BOLIVAR, Símon. Escritos políticos. Bogotá: El Áncora Edición, 1984.

DARÍO, Rubén. El triunfo de Caliban. In. Proyecto Ensayo Hispánico, 1997. Disponível em: <http://www.ensayistas.org/antologia/XIXA/dario $>$, acesso em: 23 de fevereiro de 2012.

HOMERO. Odisseia. Tradução de Antônio Pinto de Carvalho. São Paulo: Editora Nova Cultural, 2002.

FAULKNER, William. The sound and the fury. New York: Vintage International, 1991.

Revista Eletrônica da ANPHLAC, n.13, p. 227-250, jul./dez. 2012. http://revista.anphlac.org.br/index.php/revista 
JOYCE, James. Ulisses. Tradução de Bernardina da Silveira Pinheiro. Rio de Janeiro: Objetiva, 2005.

MÁRQUEZ, Gabriel García. Cem anos de solidão. Tradução de Eliane Zagury. Rio de Janeiro: Record, 2001. . Doze contos peregrinos. Tradução de Eric Nepomuceno. Rio de Janeiro: Record, 1992. . O general em seu labirinto. Tradução de Moacir Werneck de Castro. Rio de Janeiro: Record, 2007.

MARTÍ, José. Ismaelitto; Versos Libres; Versos Sencillos. $10^{\mathrm{a}}$ ed. Madrid: Ediciones Cátedra, 2001. . Nuestra America. Caracas: Biblioteca Ayacucho, 1977.

MORALES, Belén Castro. Utopía y naufragia del intelectual arielista: representaciones espaciales en José Enrique Rodó. In: ETTE, Ottmar; TITUS, Heydenreich (Org.). José Enrique Rodó y su tiempo: cien años de Ariel. $12^{\circ}$ Coloquio Interdisciplinario de la Sección Latinoamérica del Instituto Central para Regionales de La Universidad de ErlangenNurnberg. Frankfurt; Madrid: Iberoamericana, 2000. p. 95-104.

MORSE, Richard. O espelho de Próspero: cultura e ideias nas Américas. Tradução de Paulo Neves. São Paulo: Companhia das Letras, 2000.

ORDIZ, Javier. Entre Ariel e Calibán: el pensamiento modernista y la identidad de iberoamérica. Actas del $2^{\circ}$ Congreso Internacional CELEHIS de Literatura, Mar del Plata: 2004. Disponível em: < http://www.freewebs.com/celehis/actas2004/ponencias/ 50 /3_Ordiz .doc>, acesso em: 18 de fevereiro de 2012.

PLATÃo. Diálogos. Tradução de José Cavalcante de Souza, Jorge Paleikat e João Cruz Costa. São Paulo: Abril Cultural, 1983.

. A república. Tradução de Carlos Alberto Nunes. Belém: Editora UFPA, 2000.

RAMA, Ángel. Literatura, cultura e sociedade na América Latina. Tradução de Rômulo Monte Alto. Belo Horizonte: Editora UFMG, 2008.

RENAN, Ernest. Caliban: suite de “La tempête”. 2a ed. Paris: Calmann Levy, 1878.

RETAMAR, Roberto Fernández. Todo Caliban. Buenos Aires: CLACSO, 2004.

Revista Eletrônica da ANPHLAC, n.13, p. 227-250, jul./dez. 2012. http://revista.anphlac.org.br/index.php/revista 
RODÓ, José Enrique. Ariel. Madrid: Espasa-Calpe, 1991. . El mirador de Prospero. Barcelona: Cervantes, 1912.

. Motivos de Proteo / Nuevos Motivos de Proteo. Ciudad de México:

Porrua, 1993.

SAID, Edward W. Representações do intelectual: as Conferências Reith de 1993. Tradução de Milton Hatoum. São Paulo: Companhia das Letras, 2005.

SHAKESPEARE, William. Complete works. London: Wordsworth, 2007.

VAUGHAN, Alden T. \& VAUGHAN, Virginia Mason. Shakespeare's Caliban: a cultural history. New York: Cambridge University Press, 1991.

VIRGÍlLIO. Eneida. Tradução de Tassilo Orpheu Spalding. São Paulo: Editora Nova Cultural, 2003.

Revista Eletrônica da ANPHLAC, n.13, p. 227-250, jul./dez. 2012.

http://revista.anphlac.org.br/index.php/revista 